Supporting Information

\title{
Enantioselective Total Synthesis of Isishippuric Acid B via Intramolecular Michael Reaction
}

\author{
Munefumi Torihata, Takashi Nakahata, and Shigefumi Kuwahara* \\ Laboratory of Applied Bioorganic Chemistry, Graduate School of Agricultural Science, Tohoku \\ University, Tsutsumidori-Amamiyamachi, Aoba-ku, Sendai 981-8555, Japan \\ skuwahar@biochem.tohoku.ac.jp
}

\section{Contents}

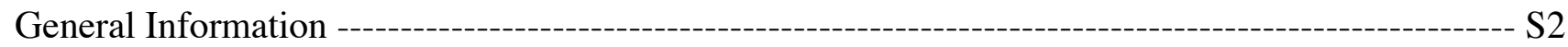

Experimental Procedures and Characterization for Compounds 7, 8, 10, 11, 14, 15, 16 and 1 --- S2-S6

${ }^{1} \mathrm{H}$ and ${ }^{13} \mathrm{C}$ NMR Spectra for Compounds 7, 8, 10, 11, 14, 15, 16 and 1 --------------------------- S7-S22 


\section{General Information}

IR spectra were recorded by a Jasco FT/IR-4100 spectrometer. NMR spectra were recorded with TMS as an internal standard in $\mathrm{CDCl}_{3}$ by a Varian Gemini 2000 spectrometer $\left(300 \mathrm{MHz}\right.$ for ${ }^{1} \mathrm{H}$ and $75 \mathrm{MHz}$ for ${ }^{13} \mathrm{C}$ ) or a Varian UNITY plus-500 spectrometer $\left(500 \mathrm{MHz}\right.$ for ${ }^{1} \mathrm{H}$ and $125 \mathrm{MHz}$ for $\left.{ }^{13} \mathrm{C}\right)$. Optical rotation values were measured with a Jasco DIP-371 polarimeter, and mass spectra were obtained with a Jeol JMS700 spectrometer operated in the EI or FAB mode. Merck silica gel 60 (70-230 mesh) or Kanto Kagaku silica gel 60N (spherical neutral, particle size 100-210 $\mu \mathrm{m}$ ) were used for column chromatography.

Dimethyl (R)-4,8-dimethyl-2-oxo-7-nonenylphosphonate (7). To a stirred solution of dimethyl methylphosphonate $(12.1 \mathrm{~mL}, 112 \mathrm{mmol})$ in THF $(150 \mathrm{~mL})$ was added dropwise $n$-BuLi (1.6 M in hexane, $70 \mathrm{~mL}, 112 \mathrm{mmol})$ at $-78{ }^{\circ} \mathrm{C}$. After $1.5 \mathrm{~h}, 6(17.6 \mathrm{~mL}, 97 \mathrm{mmol})$ in THF (200 mL) was added dropwise, and the resulting mixture was gradually warmed to $0{ }^{\circ} \mathrm{C}$ over $5 \mathrm{~h}$. The reaction mixture was quenched with sat. $\mathrm{NH}_{4} \mathrm{Cl}$ aq and concentrated in vacuo. The residue was mixed with acetone $(350 \mathrm{~mL})$, and the Jones reagent $(2.67 \mathrm{M}, 54.5 \mathrm{~mL}, 146 \mathrm{mmol})$ was added dropwise to the mixture at $0{ }^{\circ} \mathrm{C}$. After being stirred for 2 $\mathrm{h}$ at $0{ }^{\circ} \mathrm{C}$, the reaction mixture was quenched with 2-propanol, and concentrated in vacuo. The residue was diluted with water and extracted with EtOAc. The extract was successively washed with water and brine, dried $\left(\mathrm{MgSO}_{4}\right)$ and concentrated in vacuo. The residue was chromatographed over silica gel (hexane/EtOAc $=3: 2$ to $0: 1)$ to give $19.3 \mathrm{~g}(72 \%)$ of 7 as a colorless oil. $[\alpha]_{\mathrm{D}}^{24}+5.05\left(c=1.00, \mathrm{CHCl}_{3}\right)$; IR (film): $v_{\max } 1713(\mathrm{~s}), 1258$ (s), 1024 (vs); ${ }^{1} \mathrm{H}$ NMR (500 MHz): $\delta 0.91(3 \mathrm{H}, \mathrm{d}, J=6.3 \mathrm{~Hz}), 1.16-1.24$ $(1 \mathrm{H}, \mathrm{m}), 1.28-1.36(1 \mathrm{H}, \mathrm{m}), 1.60$ (3H, br s), 1.68 (3H, br s), 1.91-2.07 (3H, m), $2.44(1 \mathrm{H}, \mathrm{dd}, J=17.0,8.3$ $\mathrm{Hz}), 2.60(1 \mathrm{H}, \mathrm{dd}, J=17.0,5.4 \mathrm{~Hz}), 3.05(1 \mathrm{H}, \mathrm{dd}, J=22.5,13.7 \mathrm{~Hz}), 3.09(1 \mathrm{H}, \mathrm{dd}, J=22.5,13.7 \mathrm{~Hz})$, $3.79(6 \mathrm{H}, \mathrm{d}, J=11.2 \mathrm{~Hz}), 5.08(1 \mathrm{H}, \mathrm{t}, J=7.1 \mathrm{~Hz}) ;{ }^{13} \mathrm{C} \mathrm{NMR}(125 \mathrm{MHz}): \delta 17.5,19.4,25.3,25.6,28.4$, 36.6, $41.5(\mathrm{~d}, J=127.8 \mathrm{~Hz}), 51.3,52.9$ (d, $J=6.3 \mathrm{~Hz}), 124.1,131.4,201.6$ (d, $J=6.9 \mathrm{~Hz})$; HRMS (FAB) $m / z$ : calcd for $\mathrm{C}_{13} \mathrm{H}_{26} \mathrm{O}_{4} \mathrm{P}, 277.1569$; found, $277.1567\left([\mathrm{M}+\mathrm{H}]^{+}\right)$.

(R)-6-Methyl-2-cyclohepten-1-one (8). Ozone was bubbled into a solution of 7 (4.20 g, $15.2 \mathrm{mmol})$ in $\mathrm{CH}_{2} \mathrm{Cl}_{2}(80 \mathrm{~mL})$ at $-78^{\circ} \mathrm{C}$ for $25 \mathrm{~min}$. After removal of excess ozone by a stream of $\mathrm{O}_{2}$ (for about $15 \mathrm{~min}$ ), $\mathrm{Me}_{2} \mathrm{~S}$ (excess) was added, and the resulting mixture was gradually warmed to room temperature over $6 \mathrm{~h}$. The mixture was diluted with ether $(150 \mathrm{~mL})$, mixed with $\mathrm{LiCl}(773 \mathrm{mg}, 18.2 \mathrm{mmol})$, and stirred for 15 min. To the mixture was added dropwise DBU $(2.6 \mathrm{~mL}, 18.2 \mathrm{mmol})$, and the resulting mixture was stirred at room temperature for $2 \mathrm{~h}$. The mixture was quenched with sat. $\mathrm{NH}_{4} \mathrm{Cl}$ aq and concentrated in vacuo. The residue was diluted with water and extracted with ether. The extract was dried $\left(\mathrm{MgSO}_{4}\right)$ and concentrated in vacuo. The residue was chromatographed over silica gel (hexane/EtOAc $=10: 1)$ to give $1.45 \mathrm{~g}(77 \%)$ of 8 as a pale yellow oil. $[\alpha]_{\mathrm{D}}^{24}+59.8\left(c=1.05, \mathrm{CHCl}_{3}\right)\left[\right.$ lit. $^{7 \mathrm{a}}[\alpha]_{\mathrm{D}}^{24}+64.6\left(c=1.09, \mathrm{CHCl}_{3}\right) ; \operatorname{lit}^{7 \mathrm{~b}}[\alpha]_{\mathrm{D}}^{20}-59$ $\left(c=1.0, \mathrm{CHCl}_{3}\right.$ ) for the enantiomer of 8]; IR (film): $v_{\max } 3027(\mathrm{w}), 1664(\mathrm{~s}) ;{ }^{1} \mathrm{H} \mathrm{NMR} \mathrm{(500} \mathrm{MHz):} \delta 1.03$ $(3 \mathrm{H}, \mathrm{d}, J=6.8 \mathrm{~Hz}), 1.51-1.59(1 \mathrm{H}, \mathrm{m}), 1.89-1.96(1 \mathrm{H}, \mathrm{m}), 2.05-2.14(1 \mathrm{H}, \mathrm{m}), 2.36-2.53(3 \mathrm{H}, \mathrm{m}), 2.69$ $(1 \mathrm{H}, \mathrm{dd}, J=14.4,4.4 \mathrm{~Hz}), 6.01(1 \mathrm{H}, \mathrm{d}, J=11.7 \mathrm{~Hz}), 6.64(1 \mathrm{H}, \mathrm{dt}, J=11.7,4.9 \mathrm{~Hz}) ;{ }^{13} \mathrm{C} \mathrm{NMR}(125 \mathrm{MHz})$ : $\delta$ 22.0, 28.3, 28.4, 34.8, 51.3, 132.7, 147.3, 203.1; HRMS (EI): $m / z$ calcd for $\mathrm{C}_{8} \mathrm{H}_{12} \mathrm{O}, 124.0888$; found, 
$124.0886\left(\mathrm{M}^{+}\right)$.

Methyl (1S,2R,5R,6R)-2-methyl-8-oxobicyclo[3.2.2]nonane-6-carboxylate (10). To a stirred solution of LDA [prepared by stirring $(i \text {-Pr })_{2} \mathrm{NH}(2.97 \mathrm{~mL}, 21.2 \mathrm{mmol})$ and $n$-BuLi (1.6 M in hexane, 12.8 $\mathrm{mL}, 20.4 \mathrm{mmol})$ in $\mathrm{THF}(150 \mathrm{~mL})$ at $0{ }^{\circ} \mathrm{C}$ for $20 \mathrm{~min}$ ] was added dropwise a solution of $8(1.95 \mathrm{~g}, 15.7$ $\mathrm{mmol})$ in THF $(100 \mathrm{~mL})$ at $-78^{\circ} \mathrm{C}$. After $1 \mathrm{~h}$, TIPSCl $(5.04 \mathrm{~mL}, 23.6 \mathrm{mmol})$ and HMPA $(5.5 \mathrm{~mL})$ were successively added, and the resulting mixture was gradually warmed to $0{ }^{\circ} \mathrm{C}$ over $12 \mathrm{~h}$. The reaction mixture was quenched with sat. $\mathrm{NaHCO}_{3}$ aq and concentrated in vacuo. The residue was diluted with hexane, and the mixture was successively washed with water and brine. The hexane solution was filtered through a short column of $\mathrm{SiO}_{2}$, and the column was washed with hexane. The filtrate was concentrated in vacuo to give crude 9 as a pale yellow oil, which was used in the next step without purification. ${ }^{1} \mathrm{H}$ NMR (300 MHz): $\delta 1.02(3 \mathrm{H}, \mathrm{d}, J=6.6 \mathrm{~Hz}), 1.09(18 \mathrm{H}, \mathrm{d}, J=5.4 \mathrm{~Hz}), 1.10-1.20(3 \mathrm{H}, \mathrm{m}), 1.58-1.72(1 \mathrm{H}, \mathrm{m})$, 1.72-1.82 (1H, m), 2.24-2.32 (2H, m), 2.33-2.47 (1H, m), 5.09 (1H, dd, $J=4.8,1.3 \mathrm{~Hz}), 5.72(1 \mathrm{H}, \mathrm{dm}, J$ $=11.8 \mathrm{~Hz}), 5.83(1 \mathrm{H}, \mathrm{dt}, J=11.8,4.9 \mathrm{~Hz})$. To a stirred solution of the crude silyl enol ether $(\mathbf{9})$ obtained above in $\mathrm{CH}_{2} \mathrm{Cl}_{2}(50 \mathrm{~mL})$ was added methyl acrylate $(7.1 \mathrm{~mL}, 78.5 \mathrm{mmol})$ at $-78{ }^{\circ} \mathrm{C}$, and the mixture was stirred for $10 \mathrm{~min}$. To the solution was added dropwise $\mathrm{EtAlCl}_{2}(0.96 \mathrm{M}$ in hexane, $8.20 \mathrm{~mL}, 7.85 \mathrm{mmol})$ at $-78{ }^{\circ} \mathrm{C}$. After $2 \mathrm{~h}$, the reaction mixture was quenched with sat. $\mathrm{NaHCO}_{3}$, and extracted with EtOAc. The extract was successively washed with water and brine, dried $\left(\mathrm{MgSO}_{4}\right)$ and concentrated in vacuo. The residue was chromatographed over $\mathrm{SiO}_{2}$ (hexane/EtOAc $\left.=7: 1\right)$ to give $2.31 \mathrm{~g}(70 \%$ from $\mathbf{8})$ of 10 as a colorless oil. $[\alpha]^{24}+13.2$ ( $c=1.02, \mathrm{CHCl}_{3}$ ); IR (film): $v_{\max } 1730$ (vs), 1711 (vs), 1169 (s); ${ }^{1} \mathrm{H}$ NMR (500 $\mathrm{MHz}): \delta 1.02(3 \mathrm{H}, \mathrm{d}, J=6.8 \mathrm{~Hz}), 1.12-1.23(1 \mathrm{H}, \mathrm{m}), 1.63-1.71(2 \mathrm{H}, \mathrm{m}), 1.78-1.86(1 \mathrm{H}, \mathrm{m}), 1.94-2.01$ $(1 \mathrm{H}, \mathrm{m}), 2.10(1 \mathrm{H}, \mathrm{ddd}, J=14.7,8.3,3.9 \mathrm{~Hz}), 2.19(1 \mathrm{H}, \mathrm{dd}, J=14.7,10.7 \mathrm{~Hz}), 2.23(1 \mathrm{H}, \mathrm{d}, J=18.6 \mathrm{~Hz})$, $2.31(1 \mathrm{H}$, br s), $2.54(1 \mathrm{H}, \mathrm{dd}, J=18.6,4.9 \mathrm{~Hz}), 2.58-2.62(1 \mathrm{H}, \mathrm{m}), 2.83(1 \mathrm{H}, \mathrm{br} \mathrm{t}, J=9.0 \mathrm{~Hz}), 3.70(3 \mathrm{H}$, s); ${ }^{13} \mathrm{C}$ NMR (125 MHz): $\delta 22.7,28.0,29.9,31.9,33.9,36.7,39.7,42.7,51.9,53.4,176.2,213.5$; HRMS (FAB): $m / z$ calcd for $\mathrm{C}_{12} \mathrm{H}_{19} \mathrm{O}_{3}, 211.1334$; found, $211.1340\left([\mathrm{M}+\mathrm{H}]^{+}\right)$.

Methyl (1S,2R,5R,6R)-8,8-ethylenedioxy-2-methylbicyclo[3.2.2]nonane-6-carboxylate (11) . A mixture of $10(150 \mathrm{mg}, 0.713 \mathrm{mmol}), \mathrm{HO}\left(\mathrm{CH}_{2}\right)_{2} \mathrm{OH}(0.12 \mathrm{~mL}, 2.1 \mathrm{mmol})$ and $\mathrm{TsOH} \cdot \mathrm{H}_{2} \mathrm{O}(14 \mathrm{mg}, 71.3$ $\mu \mathrm{mol}$ ) was stirred at reflux for $2 \mathrm{~h}$. After being cooled to room temperature, the reaction mixture was quenched with sat. $\mathrm{NaHCO}_{3}$ aq, and extracted with EtOAc. The extract was successively washed with water and brine, dried $\left(\mathrm{MgSO}_{4}\right)$ and concentrated in vacuo. The residue was chromatographed over $\mathrm{SiO}_{2}$ (hexane/EtOAc $=7: 1)$ to give $166 \mathrm{mg}(91 \%)$ of 11 as a colorless oil. $[\alpha]^{24}{ }_{\mathrm{D}}-16.7\left(c=2.10, \mathrm{CHCl}_{3}\right)$; IR (film): $v_{\max } 1736(\mathrm{~s}), 1111(\mathrm{~m}) ;{ }^{1} \mathrm{H}$ NMR $(500 \mathrm{MHz}): \delta 1.06(3 \mathrm{H}, \mathrm{d}, J=6.8 \mathrm{~Hz}), 1.41-1.49(2 \mathrm{H}, \mathrm{m})$, 1.60-1.67 $(1 \mathrm{H}, \mathrm{m}), 1.74(1 \mathrm{H}, \mathrm{t}, J=3.4 \mathrm{~Hz}), 1.78-1.86(1 \mathrm{H}, \mathrm{m}), 1.88-1.98(3 \mathrm{H}, \mathrm{m}), 2.14(1 \mathrm{H}, \mathrm{ddd}, J=$ $14.2,7.8,3.9 \mathrm{~Hz}), 2.18(1 \mathrm{H}, \mathrm{dd}, J=15.1,5.9 \mathrm{~Hz}), 2.41(1 \mathrm{H}$, br t, $J=6.1 \mathrm{~Hz}), 2.58(1 \mathrm{H}$, br t, $J=9.3 \mathrm{~Hz})$, $3.67(3 \mathrm{H}, \mathrm{s}), 3.78-3.83(1 \mathrm{H}, \mathrm{m}), 3.87-3.93(2 \mathrm{H}, \mathrm{m}), 3.94-3.99(1 \mathrm{H}, \mathrm{m}): \delta 24.4,28.5,28.8,31.6,35.2$, 36.1, 37.1, 43.2, 44.1, 51.4, 63.0, 64.2, 110.9, 176.4; HRMS (EI): $m / z$ calcd for $\mathrm{C}_{14} \mathrm{H}_{22} \mathrm{O}_{4}, 254.1518$; found, $254.1515\left(\mathrm{M}^{+}\right)$. 
$(1 R, 4 R, 5 S)-4,8,8$-trimethylbicyclo[3.2.2]nonan-6-one (14). To a stirred solution of LDA [prepared from $(i-\mathrm{Pr})_{2} \mathrm{NH}(1.10 \mathrm{~mL}, 7.87 \mathrm{mmol})$ and $n$-BuLi $(1.6 \mathrm{M}$ in hexane, $4.74 \mathrm{~mL}, 7.59 \mathrm{mmol})$ in THF (70 $\mathrm{mL})$ ] was added dropwise a solution of $11(1.43 \mathrm{~g}, 5.62 \mathrm{mmol})$ in THF $(50 \mathrm{~mL})$ at $-78{ }^{\circ} \mathrm{C}$. After $50 \mathrm{~min}$, a solution of MeI $(1.15 \mathrm{~mL}, 18.0 \mathrm{mmol})$ in $\mathrm{HMPA}(3.2 \mathrm{~mL})$ was added at $-78{ }^{\circ} \mathrm{C}$, and the resulting mixture was gradually warmed to $0{ }^{\circ} \mathrm{C}$ over $7 \mathrm{~h}$. The reaction mixture was quenched with sat. $\mathrm{NH}_{4} \mathrm{Cl}$ aq and concentrated in vacuo. The residue was diluted with water, and extracted with ether. The extract was successively washed with water and brine, dried $\left(\mathrm{MgSO}_{4}\right)$ and concentrated in vacuo to give crude 12 as a pale yellow oil, which was used in the next step without purification. ${ }^{1} \mathrm{H}$ NMR $(300 \mathrm{MHz}): \delta 1.03(3 \mathrm{H}, \mathrm{d}, J$ $=6.6 \mathrm{~Hz}), 1.15-1.26(1 \mathrm{H}, \mathrm{m}), 1.35(3 \mathrm{H}, \mathrm{s}), 1.32-1.39(1 \mathrm{H}, \mathrm{m}), 1.55-1.77(5 \mathrm{H}, \mathrm{m}), 1.97(1 \mathrm{H}, \mathrm{d}, J=13.8$ $\mathrm{Hz}), 2.16-2.28(2 \mathrm{H}, \mathrm{m}), 2.61(1 \mathrm{H}, \mathrm{dd}, J=13.8,1.8 \mathrm{~Hz}), 3.69(3 \mathrm{H}, \mathrm{s}), 3.82-4.00(4 \mathrm{H}, \mathrm{m})$. To a stirred suspension of LAH (427 mg, $11.2 \mathrm{mmol})$ in ether $(70 \mathrm{~mL})$ was added dropwise a solution of the crude ester (12) obtained above in ether $(40 \mathrm{~mL})$ at $0{ }^{\circ} \mathrm{C}$. After $3 \mathrm{~h}$, the reaction mixture was quenched with sat. $\mathrm{NH}_{4} \mathrm{Cl}$ aq and extracted with ether. The extract was successively washed with water and brine, dried $\left(\mathrm{MgSO}_{4}\right)$ and concentrated in vacuo to give an alcohol as an colorless oil, which was used in the next step without purification. ${ }^{1} \mathrm{H}$ NMR $(300 \mathrm{MHz}): \delta 1.03(3 \mathrm{H}, \mathrm{d}, J=6.9 \mathrm{~Hz}), 1.12-1.20(1 \mathrm{H}, \mathrm{m}), 1.15(3 \mathrm{H}, \mathrm{s})$, 1.30-1.36 (1H, m), 1.38-1.46 (1H, m), 1.50-1.82 (6H, m), $1.85(1 \mathrm{H}$, br t, $J=7.3 \mathrm{~Hz}), 1.96(1 \mathrm{H}, \mathrm{dd}, J=$ 15.7, 1.6 Hz), $2.22(1 \mathrm{H}, \mathrm{dd}, J=15.7,5.8 \mathrm{~Hz}), 3.33(1 \mathrm{H}, \mathrm{dd}, J=11.0,3.6 \mathrm{~Hz}), 3.69(1 \mathrm{H}, \mathrm{dd}, J=11.0,3.6$ $\mathrm{Hz}), 3.81-4.01(4 \mathrm{H}, \mathrm{m})$. To a stirred solution of the crude alcohol obtained above and $\mathrm{Et}_{3} \mathrm{~N}(2.74 \mathrm{~mL}, 19.7$ mmol $)$ in $\mathrm{CH}_{2} \mathrm{Cl}_{2}(50 \mathrm{~mL})$ was added dropwise $\mathrm{MsCl}(0.87 \mathrm{~mL}, 11.2 \mathrm{mmol})$ at $0{ }^{\circ} \mathrm{C}$. After $1 \mathrm{~h}$, the reaction mixture was quenched with sat. $\mathrm{NH}_{4} \mathrm{Cl}$ aq and extracted with ether. The extract was successively washed with water and brine, dried $\left(\mathrm{MgSO}_{4}\right)$ and concentrated in vacuo to give crude $\mathbf{1 3}$ as a pale yellow oil, which was used in the next step without purification. ${ }^{1} \mathrm{H}$ NMR $(300 \mathrm{MHz}): \delta 1.03(3 \mathrm{H}, \mathrm{d}, J=6.6 \mathrm{~Hz}), 1.21(3 \mathrm{H}$, s), $1.25(1 \mathrm{H}, \mathrm{d}, J=12.6 \mathrm{~Hz}), 1.41-1.47(1 \mathrm{H}, \mathrm{m}), 1.47-1.79(6 \mathrm{H}, \mathrm{m}), 1.88(1 \mathrm{H}, \mathrm{br} \mathrm{t}, J=6.2 \mathrm{~Hz}), 1.97(1 \mathrm{H}$, $\mathrm{dd}, J=15.7,1.6 \mathrm{~Hz}), 2.22(1 \mathrm{H}, \mathrm{dd}, J=15.7,6.0 \mathrm{~Hz}), 3.02(3 \mathrm{H}, \mathrm{s}), 3.80-4.02(5 \mathrm{H}, \mathrm{m}), 4.23(1 \mathrm{H}, \mathrm{d}, J=9.3$ $\mathrm{Hz})$. To a stirred solution of the crude mesylate (13) obtained above in HMPA (100 mL) was successively added $\mathrm{NaI}(4.20 \mathrm{~g}, 28.1 \mathrm{mmol})$ and $\mathrm{Zn}$ powder $(3.70 \mathrm{~g}, 56.2 \mathrm{mmol})$ at room temperature. The mixture was then stirred at $110^{\circ} \mathrm{C}$ for $25 \mathrm{~h}$. After being cooled to room temperature, the mixture was filtered and diluted with hexane. The hexane solution was successively washed with water and brine, dried $\left(\mathrm{MgSO}_{4}\right)$ and concentrated in vacuo to give the ethylene acetal of $\mathbf{1 4}$ as an oil, which was used in the next step without purification. ${ }^{1} \mathrm{H}$ NMR $(300 \mathrm{MHz}): \delta 1.02(3 \mathrm{H}, \mathrm{d}, J=6.6 \mathrm{~Hz}), 1.05(3 \mathrm{H}, \mathrm{s}), 1.07(3 \mathrm{H}, \mathrm{s}), 1.36(1 \mathrm{H}, \mathrm{dd}, J=$ $14.2,1.9 \mathrm{~Hz}), 1.39-1.46(1 \mathrm{H}, \mathrm{m}), 1.48-1.74(5 \mathrm{H}, \mathrm{m}), 1.79(1 \mathrm{H}, \mathrm{dd}, J=14.2,5.5 \mathrm{~Hz}), 1.83-1.92(1 \mathrm{H}, \mathrm{m})$, $1.92(1 \mathrm{H}, \mathrm{dd}, J=15.4,1.4 \mathrm{~Hz}), 2.26(1 \mathrm{H}, \mathrm{dd}, J=15.4,5.5 \mathrm{~Hz}), 3.81-4.00(4 \mathrm{H}, \mathrm{m})$. A solution of the crude acetal obtained above in acetone $(40 \mathrm{~mL})$ was mixed with $1 \mathrm{M} \mathrm{HCl} \mathrm{aq}(1.5 \mathrm{~mL})$ and stirred at room temperature for $1 \mathrm{~h}$. The reaction mixture was quenched with sat. $\mathrm{NaHCO}_{3}$ aq, and concentrated in vacuo. The residue was diluted with water and extracted with ether. The extract was successively washed with water and brine, dried $\left(\mathrm{MgSO}_{4}\right)$ and concentrated in vacuo. The residue was chromatographed over $\mathrm{SiO}_{2}$ (hexane/EtOAc $=30: 1)$ to give $851 \mathrm{mg}\left(84 \%\right.$ from 11) of 14 as a colorless oil. $[\alpha]_{\mathrm{D}}^{24}+22.9(c=1.26$, $\mathrm{CHCl}_{3}$ ); IR (film): $v_{\max } 1711(\mathrm{~s}) ;{ }^{1} \mathrm{H}$ NMR (500 MHz): $\delta 0.94(3 \mathrm{H}, \mathrm{d}, J=6.8 \mathrm{~Hz}), 1.03(3 \mathrm{H}, \mathrm{s})$, 
1.11-1.21 (1H, m), $1.16(3 \mathrm{H}, \mathrm{s}), 1.64-1.76(4 \mathrm{H}, \mathrm{m}), 1.77-1.82(1 \mathrm{H}, \mathrm{m}), 1.82-1.91(1 \mathrm{H}, \mathrm{m}), 2.02-2.10$ $(1 \mathrm{H}, \mathrm{m}), 2.17(1 \mathrm{H}, \mathrm{dd}, J=19.5,1.5 \mathrm{~Hz}), 2.18-2.21(1 \mathrm{H}, \mathrm{m}), 2.58(1 \mathrm{H}, \mathrm{dd}, J=19.5,5.4 \mathrm{~Hz}): \delta 22.2,26.4$, 30.0, 30.7, 31.5, 32.4, 38.5, 40.3, 40.6, 41.7, 54.7, 215.8; HRMS (EI): $\mathrm{m} / z$ calcd for $\mathrm{C}_{12} \mathrm{H}_{20} \mathrm{O}, 180.1514$; found, $180.1518\left(\mathrm{M}^{+}\right)$.

\section{Methyl (1S,2R,5R)-5-[2-(tert-butoxycarbonyl)vinyl]-2,6,6-trimethylcycloheptane-1-carboxylate} (15). To a stirred a solution of NaHMDS (1.03 M in THF, $2.83 \mathrm{~mL}, 2.91 \mathrm{mmol})$ in DMF/HMPA (5:2, 14 $\mathrm{mL}$ ) was added dropwise a solution of $14(420 \mathrm{mg}, 2.33 \mathrm{mmol})$ in DMF $(10 \mathrm{~mL})$ at $0{ }^{\circ} \mathrm{C}$. After $20 \mathrm{~min}$, $\mathrm{Me}_{2} \mathrm{SO}_{4}(0.300 \mathrm{~mL}, 3.14 \mathrm{mmol})$ was added dropwise, and the mixture was gradually warmed to room temperature over $2 \mathrm{~h}$. The reaction mixture was quenched with sat. $\mathrm{NaHCO}_{3}$ aq and extracted with hexane. The hexane solution was successively washed with water and brine, dried $\left(\mathrm{MgSO}_{4}\right)$ and concentrated in vacuo to give a methyl enol ether as a pale yellow oil, which was used in the next step without purification. ${ }^{1} \mathrm{H}$ NMR (300 MHz): $\delta 0.90(3 \mathrm{H}, \mathrm{d}, J=6.9 \mathrm{~Hz}), 0.95(3 \mathrm{H}, \mathrm{s}), 1.07-1.17(1 \mathrm{H}, \mathrm{m}), 1.10(3 \mathrm{H}, \mathrm{s}), 1.35-1.56$ $(3 \mathrm{H}, \mathrm{m}), 1.59-1.73(3 \mathrm{H}, \mathrm{m}), 1.88-1.95(1 \mathrm{H}, \mathrm{m}), 2.01-2.07(1 \mathrm{H}, \mathrm{m}), 3.53(3 \mathrm{H}, \mathrm{s}), 4.79(1 \mathrm{H}, \mathrm{dd}, J=8.0,2.2$ $\mathrm{Hz})$. Ozone was bubbled into a solution of the crude enol ether obtained above and pyridine $(0.380 \mathrm{~mL}$, $4.66 \mathrm{mmol}$ ) in $\mathrm{MeOH}(25 \mathrm{~mL})$ at $-78{ }^{\circ} \mathrm{C}$ for $5 \mathrm{~min}$. After removal of excess ozone by a stream of $\mathrm{O}_{2}$ (for about $15 \mathrm{~min}$ ), $\mathrm{Me}_{2} \mathrm{~S}$ (excess) was added, and the resulting mixture was gradually warmed to room temperature over $12 \mathrm{~h}$. The mixture was concentrated in vacuo. The residue was diluted with a mixture of hexane and EtOAc (15:1) and filtered through a pad of $\mathrm{SiO}_{2}$. The filtrate was concentrated in vacuo to give a formyl ester, which was used in the next step without purification. ${ }^{1} \mathrm{H}$ NMR $(300 \mathrm{MHz}): \delta 0.89(3 \mathrm{H}, \mathrm{d}, J$ $=6.9 \mathrm{~Hz}), 0.92(3 \mathrm{H}, \mathrm{s}), 1.19-1.28(1 \mathrm{H}, \mathrm{m}), 1.21(3 \mathrm{H}, \mathrm{s}), 1.40-1.87(5 \mathrm{H}, \mathrm{m}), 2.01(1 \mathrm{H}, \mathrm{br} \mathrm{d}, J=9.3 \mathrm{~Hz})$, 2.37-2.51 (1H, m), $2.61(1 \mathrm{H}, \mathrm{dd}, J=9.3,3.0 \mathrm{~Hz}), 3.68(3 \mathrm{H}, \mathrm{s}), 9.74(1 \mathrm{H}, \mathrm{d}, J=1.9 \mathrm{~Hz})$. To a stirred solution of $\mathrm{Ph}_{3} \mathrm{P}=\mathrm{CHCO}_{2} t-\mathrm{Bu}(1.05 \mathrm{~g}, 2.80 \mathrm{mmol})$ in toluene $(10 \mathrm{~mL})$ was added dropwise a solution of the formyl ester obtained above in toluene $(10 \mathrm{~mL})$ at room temperature, and the mixture was stirred at 60 ${ }^{\circ} \mathrm{C}$ for 1 day. The mixture was diluted with ether, and the ethereal solution was successively washed with water and brine, dried $\left(\mathrm{MgSO}_{4}\right)$ and concentrated in vacuo. The residue was chromatographed over $\mathrm{SiO}_{2}$ (hexane/EtOAc $=40: 1)$ to give $377 \mathrm{mg}\left(50 \%\right.$ from 14) of 15 as a white solid $\left(\mathrm{mp} 79-80{ }^{\circ} \mathrm{C}\right) .[\alpha]^{24}{ }_{\mathrm{D}}-31.2$ $\left(c=0.110, \mathrm{CHCl}_{3}\right.$ ); IR (film): $v_{\max } 1734$ (s), 1712 (vs), 1650 (w), 1155 (s), 1140 (vs); ${ }^{1} \mathrm{H}$ NMR (500 MHz): $\delta 0.83(3 \mathrm{H}, \mathrm{s}), 0.87(3 \mathrm{H}, \mathrm{d}, J=6.8 \mathrm{~Hz}), 0.93(3 \mathrm{H}, \mathrm{s}), 1.29-1.36(1 \mathrm{H}, \mathrm{m}), 1.48(9 \mathrm{H}, \mathrm{s}), 1.58-1.70$ $(4 \mathrm{H}, \mathrm{m}), 1.75(1 \mathrm{H}, \mathrm{dd}, J=15.1,9.8 \mathrm{~Hz}), 1.93(1 \mathrm{H}, \mathrm{t}, J=8.5 \mathrm{~Hz}), 2.37-2.44(1 \mathrm{H}, \mathrm{m}), 2.64(1 \mathrm{H}, \mathrm{dd}, J=9.8$, $2.4 \mathrm{~Hz}), 3.67(3 \mathrm{H}, \mathrm{s}), 5.63(1 \mathrm{H}, \mathrm{d}, J=15.6 \mathrm{~Hz}), 6.79(1 \mathrm{H}, \mathrm{dd}, J=15.6,9.8 \mathrm{~Hz}): \delta$ 15.0, 24.1, 26.0, 28.06, 28.14, 32.4, 35.2, 35.9, 36.1, 42.7, 51.6, 52.1, 80.0, 122.0, 150.5, 166.1, 176.5; HRMS (EI): $\mathrm{m} / \mathrm{z}$ calcd for $\mathrm{C}_{19} \mathrm{H}_{32} \mathrm{O}_{4}, 324.2301$; found, $324.2301\left(\mathrm{M}^{+}\right)$.

\section{Methyl $(1 R, 2 R, 5 R, 8 R)-8$-[(tert-butoxycarbonyl)methyl]-2,6,6-trimethylbicyclo[3.2.1]octane-1-} carboxylate (16). To a stirred solution of LHMDS [prepared by stirring (TMS) ${ }_{2} \mathrm{NH}(83 \mu \mathrm{L}, 398 \mu \mathrm{mol})$ and $n$-BuLi (1.6 M in hexane, $250 \mu \mathrm{L}, 398 \mu \mathrm{mol})$ in $\mathrm{THF}(3 \mathrm{~mL})$ at $0{ }^{\circ} \mathrm{C}$ for $\left.20 \mathrm{~min}\right]$ was added dropwise a solution of $\mathbf{1 5}(86 \mathrm{mg}, 27 \mu \mathrm{mol})$ in a mixture of THF $(3 \mathrm{~mL})$ and $\mathrm{HMPA}(0.35 \mathrm{~mL})$ at $0{ }^{\circ} \mathrm{C}$. After being 
stirred for $2 \mathrm{~h}$ at $0{ }^{\circ} \mathrm{C}$, the reaction mixture was quenched with sat. $\mathrm{NH}_{4} \mathrm{Cl}$ aq and extracted with ether. The extract was washed with water and brine, dried $\left(\mathrm{MgSO}_{4}\right)$ and concentrated in vacuo. The residue was chromatographed over $\mathrm{SiO}_{2}$ (hexane/EtOAc $=50: 1$ ) to give $47 \mathrm{mg}(55 \%)$ of 16 as a colorless oil and 20 $\mathrm{mg}(23 \%)$ of its $(8 S)$-epimer (17) as a colorless oil. 16: $[\alpha]_{\mathrm{D}}^{24}-8.6\left(c=0.80, \mathrm{CHCl}_{3}\right)$; IR (film): $v_{\max } 1733$ (s); ${ }^{1} \mathrm{H}$ NMR (500 MHz): $\delta 1.03(3 \mathrm{H}, \mathrm{d}, J=7.3 \mathrm{~Hz}), 1.12(3 \mathrm{H}, \mathrm{s}), 1.13(3 \mathrm{H}, \mathrm{s}), 1.24-1.30(1 \mathrm{H}, \mathrm{m}), 1.47$ (9H, s), 1.59-1.65 (2H, m), 1.65-1.71 (1H, m), $1.74(1 \mathrm{H}, \mathrm{d}, J=14.2 \mathrm{~Hz}), 1.99-2.08$ (2H, m), 2.05 (1H, d, $J=14.2 \mathrm{~Hz}), 2.21(1 \mathrm{H}, \mathrm{dd}, J=16.1,6.3 \mathrm{~Hz}), 2.62(1 \mathrm{H}$, br t, $J=6.8 \mathrm{~Hz}), 2.81(1 \mathrm{H}, \mathrm{dd}, J=16.1,7.8 \mathrm{~Hz})$, $3.61(3 \mathrm{H}, \mathrm{s}) ;{ }^{13} \mathrm{C} \mathrm{NMR}(125 \mathrm{MHz}): \delta$ 18.2, 26.3, 26.4, 27.5, 28.2, 34.3, 37.7, 39.7, 40.1, 42.5, 48.8, 51.1, 51.5, 59.4, 79.8, 172.6, 176.1; HRMS (FAB): $\mathrm{m} / \mathrm{z}$ calcd for $\mathrm{C}_{19} \mathrm{H}_{33} \mathrm{O}_{4}, 325.2379$; found, 325.2378 $\left([\mathrm{M}+\mathrm{H}]^{+}\right)$.

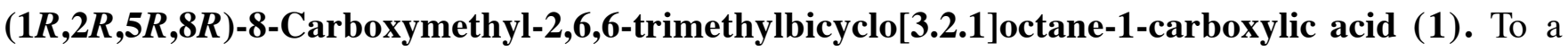
stirred solution of 16 (21 mg, $65 \mu \mathrm{mol})$ in THF (3 mL) was successively added $t$-BuOK (145 mg, 1.29 mmol) and water $(10 \mu \mathrm{L}, 520 \mu \mathrm{mol})$, and the mixture was stirred at $50{ }^{\circ} \mathrm{C}$ for $36 \mathrm{~h}$. The reaction mixture was quenched with $1 \mathrm{M} \mathrm{HCl}$ aq, stirred for an additional $10 \mathrm{~min}$, and extracted with $\mathrm{CH}_{2} \mathrm{Cl}_{2}$. The extract was successively washed with water and brine, dried $\left(\mathrm{MgSO}_{4}\right)$ and concentrated in vacuo. The residue was chromatographed over $\mathrm{SiO}_{2}\left(\mathrm{CHCl}_{3} / \mathrm{MeOH} / \mathrm{AcOH}=100: 2: 1\right)$ to give $14 \mathrm{mg}(85 \%)$ of 1 as a white solid. $[\alpha]_{\mathrm{D}}^{24}-104\left(c=0.075, \mathrm{CHCl}_{3}\right.$ ); IR (film): $v_{\max } 1700(\mathrm{vs}), 1409(\mathrm{w}), 1290(\mathrm{~m}), 937(\mathrm{w}) ;{ }^{1} \mathrm{H}$ NMR (500 MHz, pyridine- $\left.d_{5}\right): \delta 1.10(3 \mathrm{H}, \mathrm{s}), 1.23-1.27(1 \mathrm{H}, \mathrm{m}), 1.27(3 \mathrm{H}, \mathrm{s}), 1.36(3 \mathrm{H}, \mathrm{d}, J=6.8 \mathrm{~Hz}), 1.58-1.64$ $(1 \mathrm{H}, \mathrm{m}), 1.74-1.82(1 \mathrm{H}, \mathrm{m}), 1.85(1 \mathrm{H}, \mathrm{br} \mathrm{s}), 1.96(1 \mathrm{H}, \mathrm{d}, J=14.2 \mathrm{~Hz}), 2.04-2.13(1 \mathrm{H}, \mathrm{m}), 2.36-2.43(1 \mathrm{H}$, m), $2.45(1 \mathrm{H}, \mathrm{d}, J=14.2 \mathrm{~Hz}), 2.73(1 \mathrm{H}, \mathrm{dd}, J=16.1,7.3 \mathrm{~Hz}), 3.16(1 \mathrm{H}, \mathrm{br} \mathrm{t}, J=7.3 \mathrm{~Hz}), 3.64(1 \mathrm{H}, \mathrm{dd}, J=$ 16.1, $7.8 \mathrm{~Hz}) ;{ }^{13} \mathrm{C}$ NMR (125 MHz, pyridine- $\left.d_{5}\right): \delta 19.2,27.2,27.3,28.5,35.2,38.4,40.3,40.5,44.0,50.1$, 52.4, 60.3, 176.4, 178.9; HRMS (FAB): $m / z$ calcd for $\mathrm{C}_{14} \mathrm{H}_{23} \mathrm{O}_{4}, 255.1596$; found, $255.1604\left([\mathrm{M}+\mathrm{H}]^{+}\right)$. 


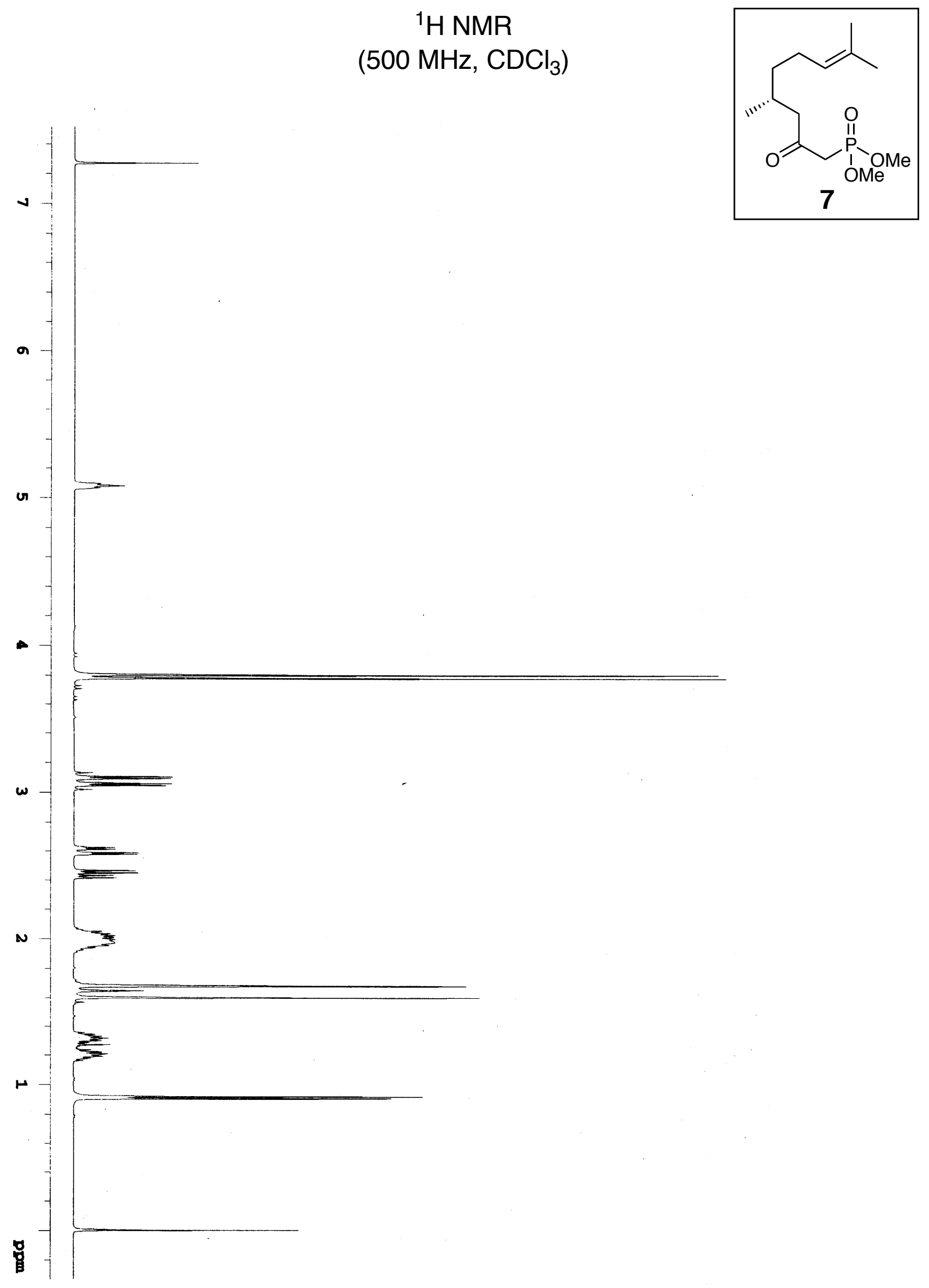


${ }^{13} \mathrm{C}$ NMR

(125 MHz, $\mathrm{CDCl}_{3}$ )

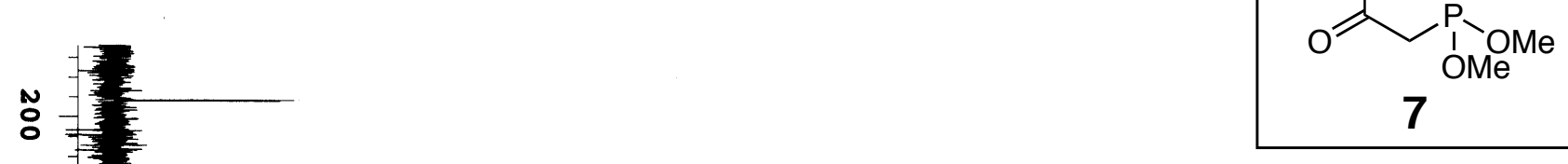

占

崩

宛

$\stackrel{\infty}{\circ}$

농

\&

-1 章章

응

:

-

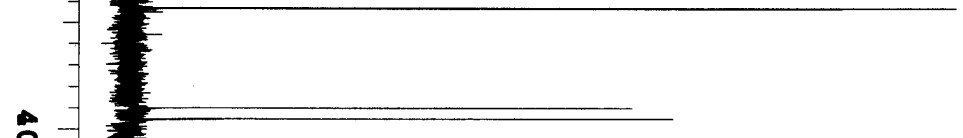

望 
${ }^{1} \mathrm{H}$ NMR
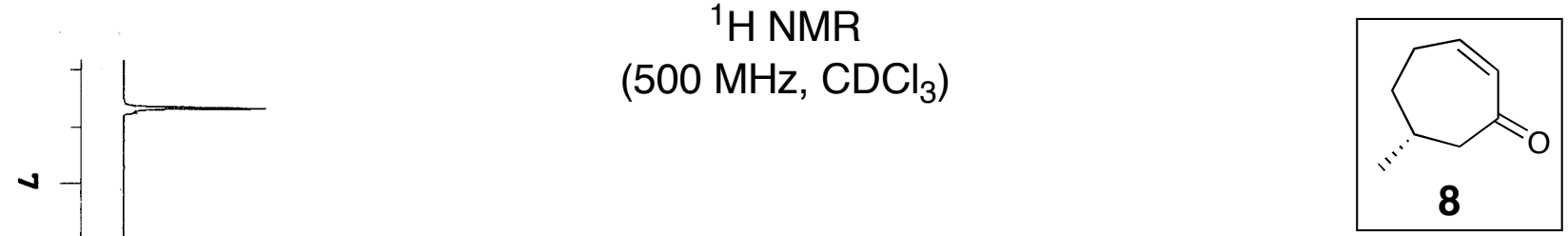

v

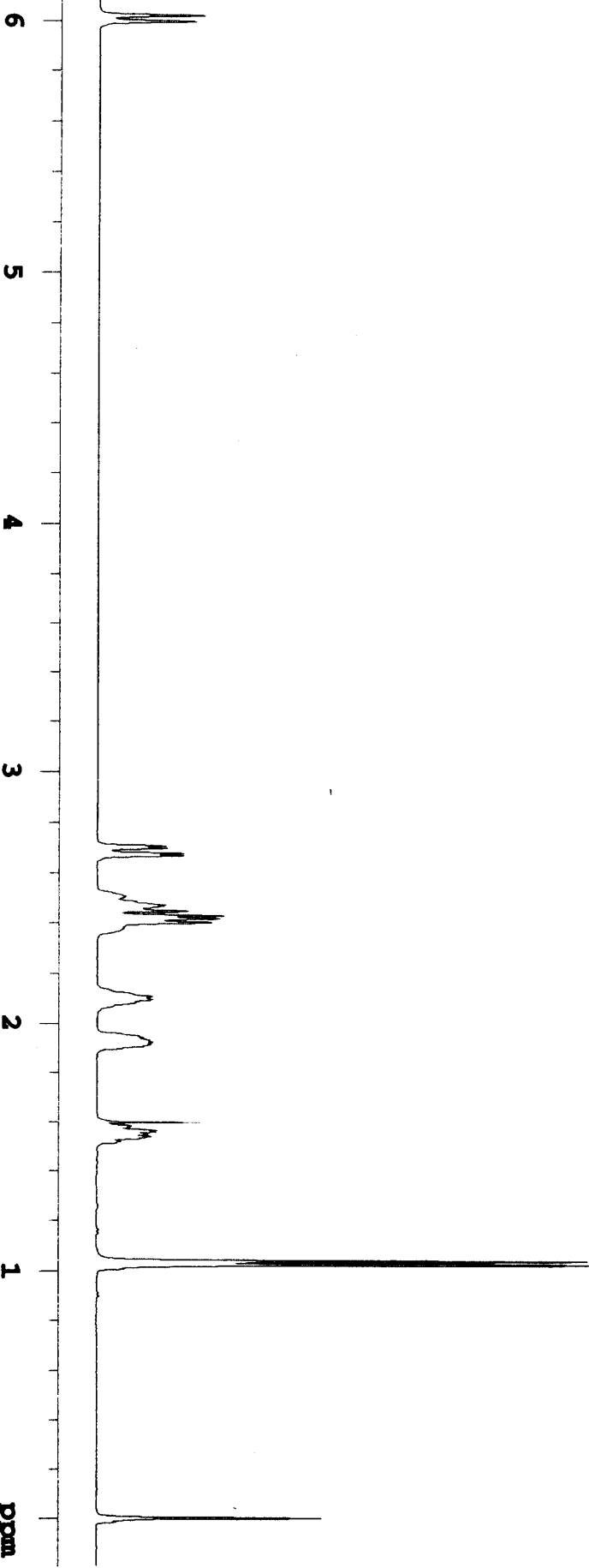


${ }^{13} \mathrm{C}$ NMR

(125 MHz, $\mathrm{CDCl}_{3}$ )

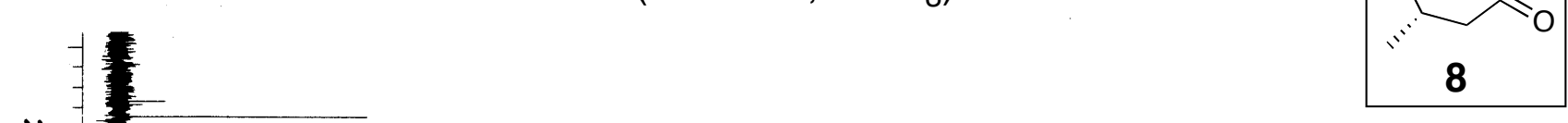

㤐

เั

s

능

:

今.

客

๕

-

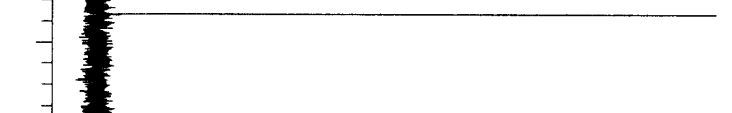

武㲤

o

\&

-

it 
${ }^{1} \mathrm{H}$ NMR

(500 MHz, $\mathrm{CDCl}_{3}$ )

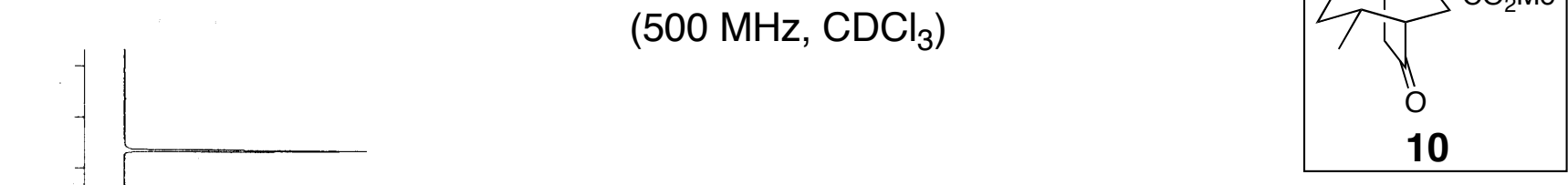

$\checkmark$

$a$

v
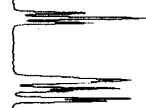

$\equiv$

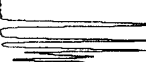

N
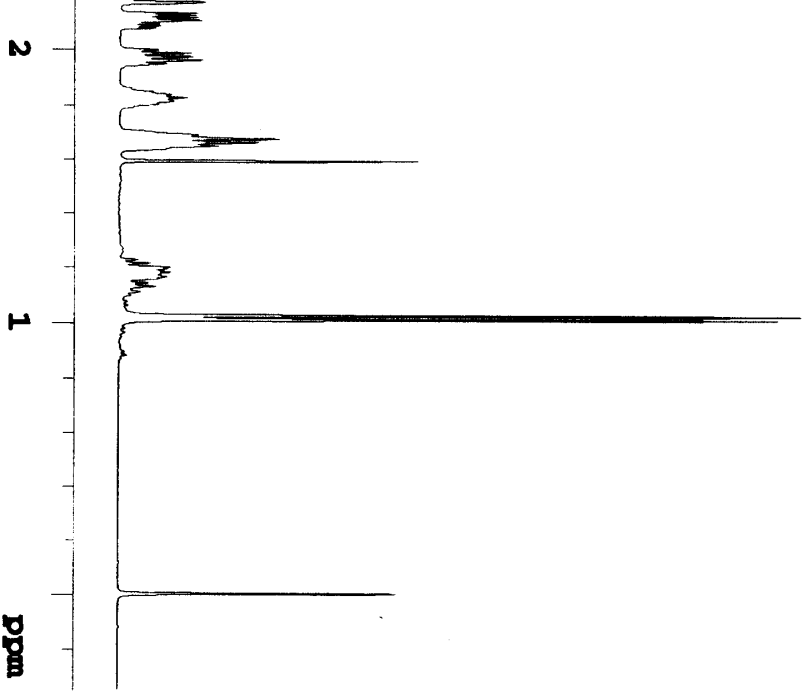

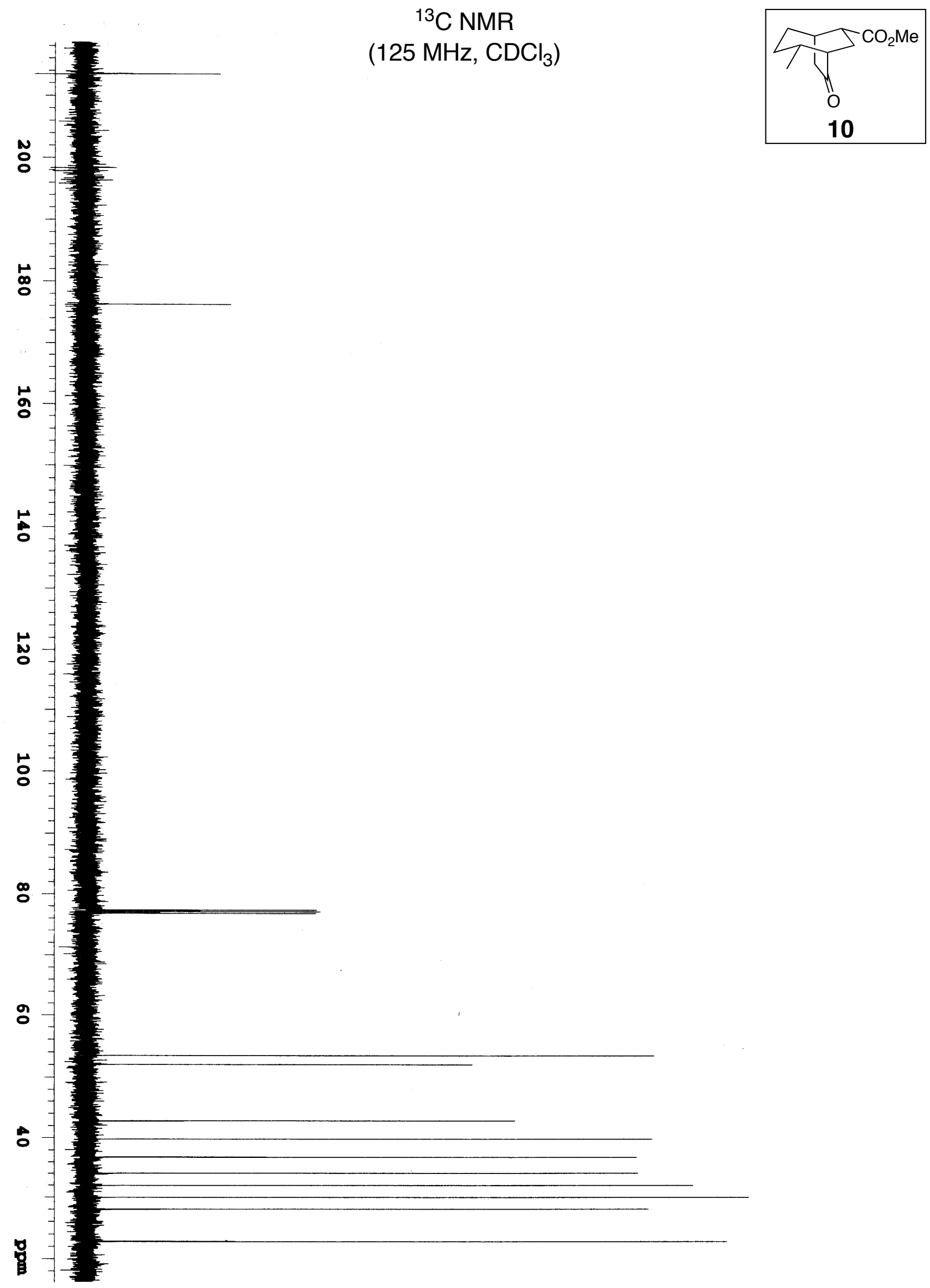

S12 


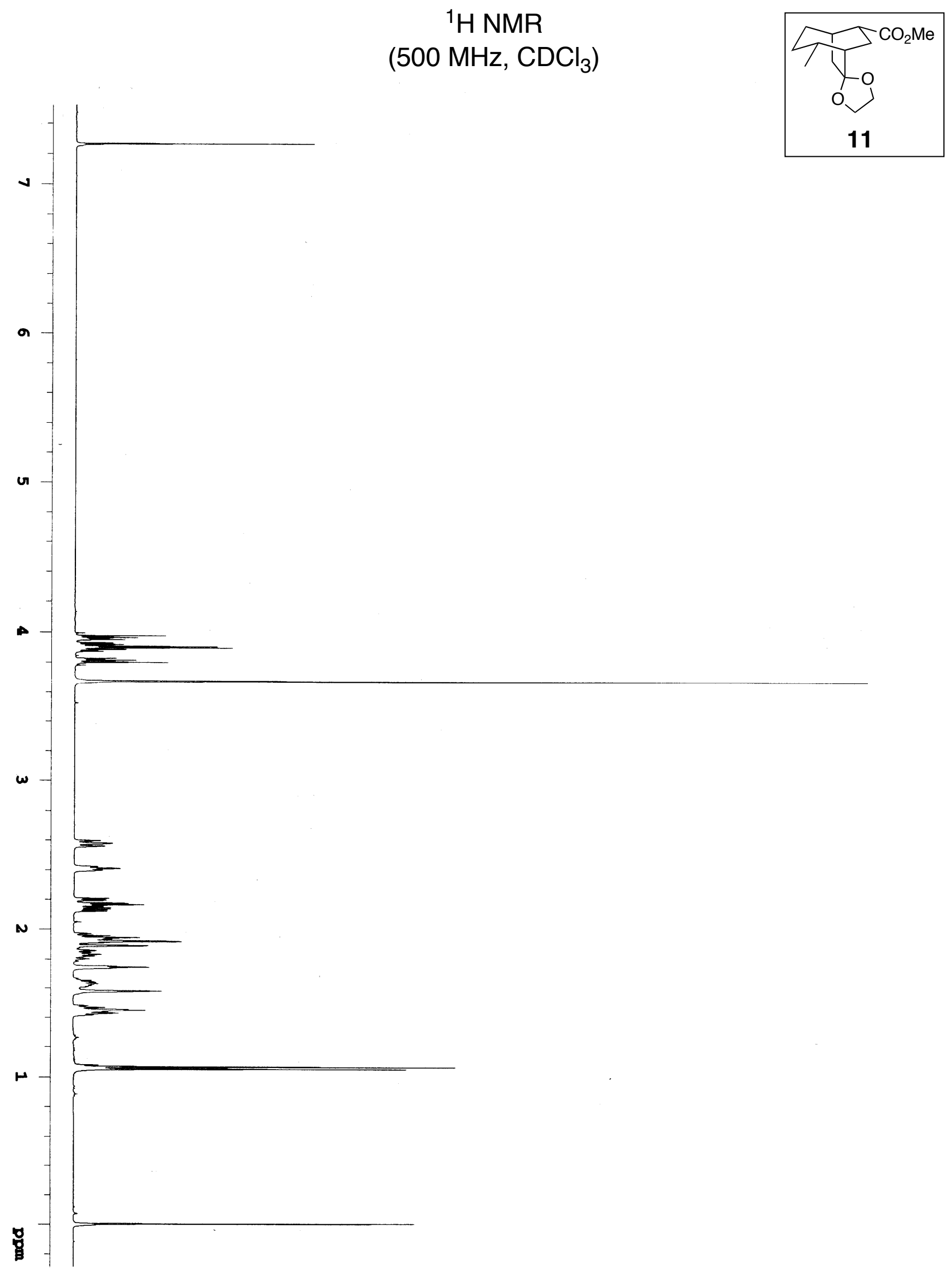


${ }^{13} \mathrm{C}$ NMR

(125 MHz, $\mathrm{CDCl}_{3}$ )

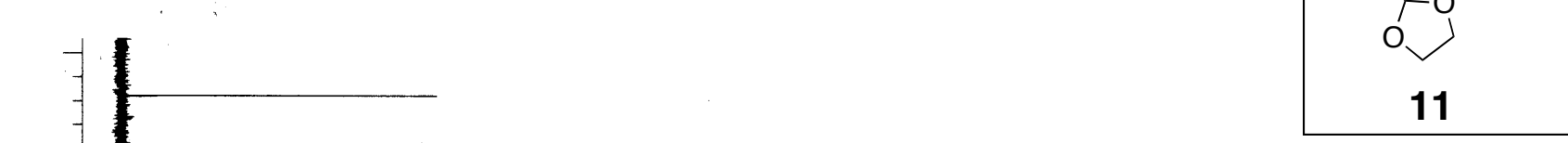

$4 \sum_{0}^{\mathrm{O}_{0}} \mathrm{CO}_{2} \mathrm{Me}$

11

$\stackrel{\infty}{\circ}$

몽

$\stackrel{\leftrightarrow}{\circ}$

봉

봉

웅

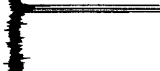

ㅇ

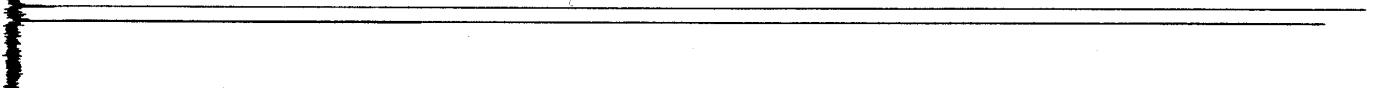

。

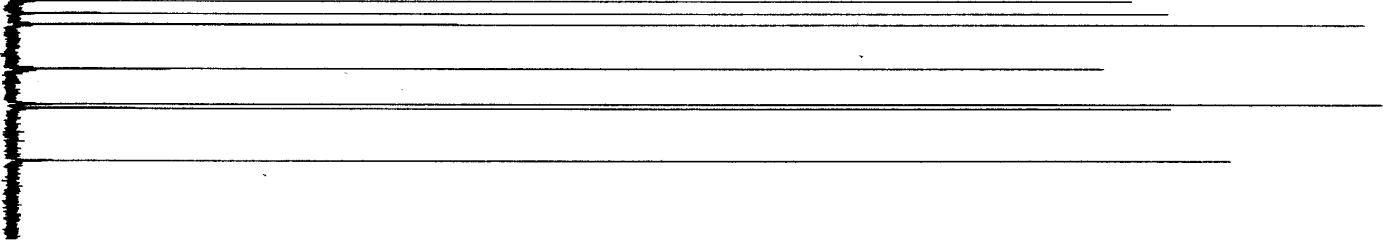




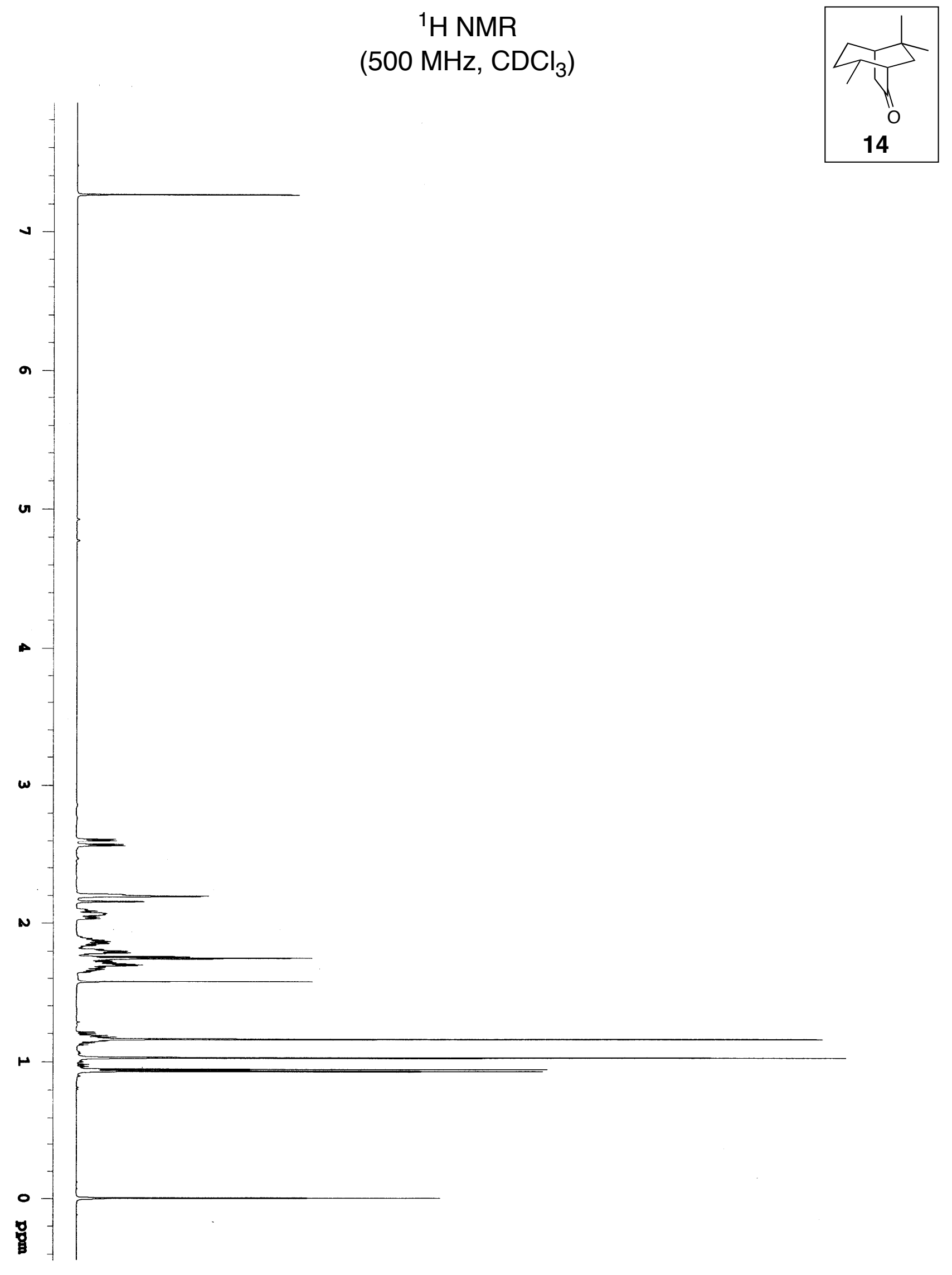


${ }^{13} \mathrm{C}$ NMR

(125 MHz, $\mathrm{CDCl}_{3}$ )

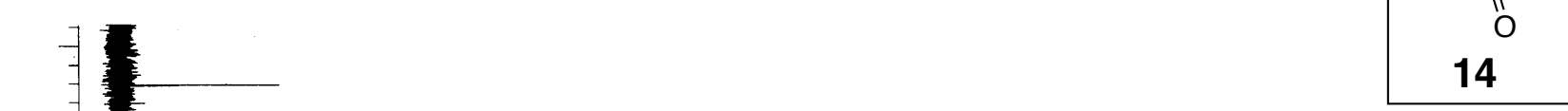

ฉั

品

学

:

:

:

品

。

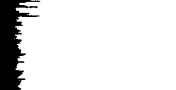

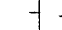

正

手

-

寻

(1)

ㅇ
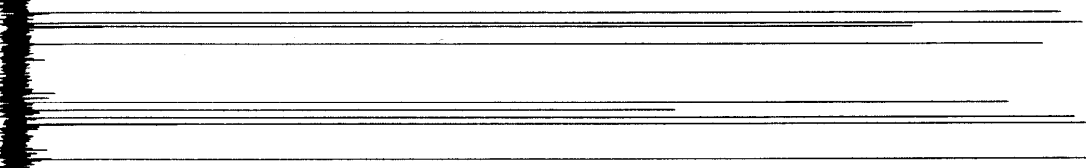

胃 

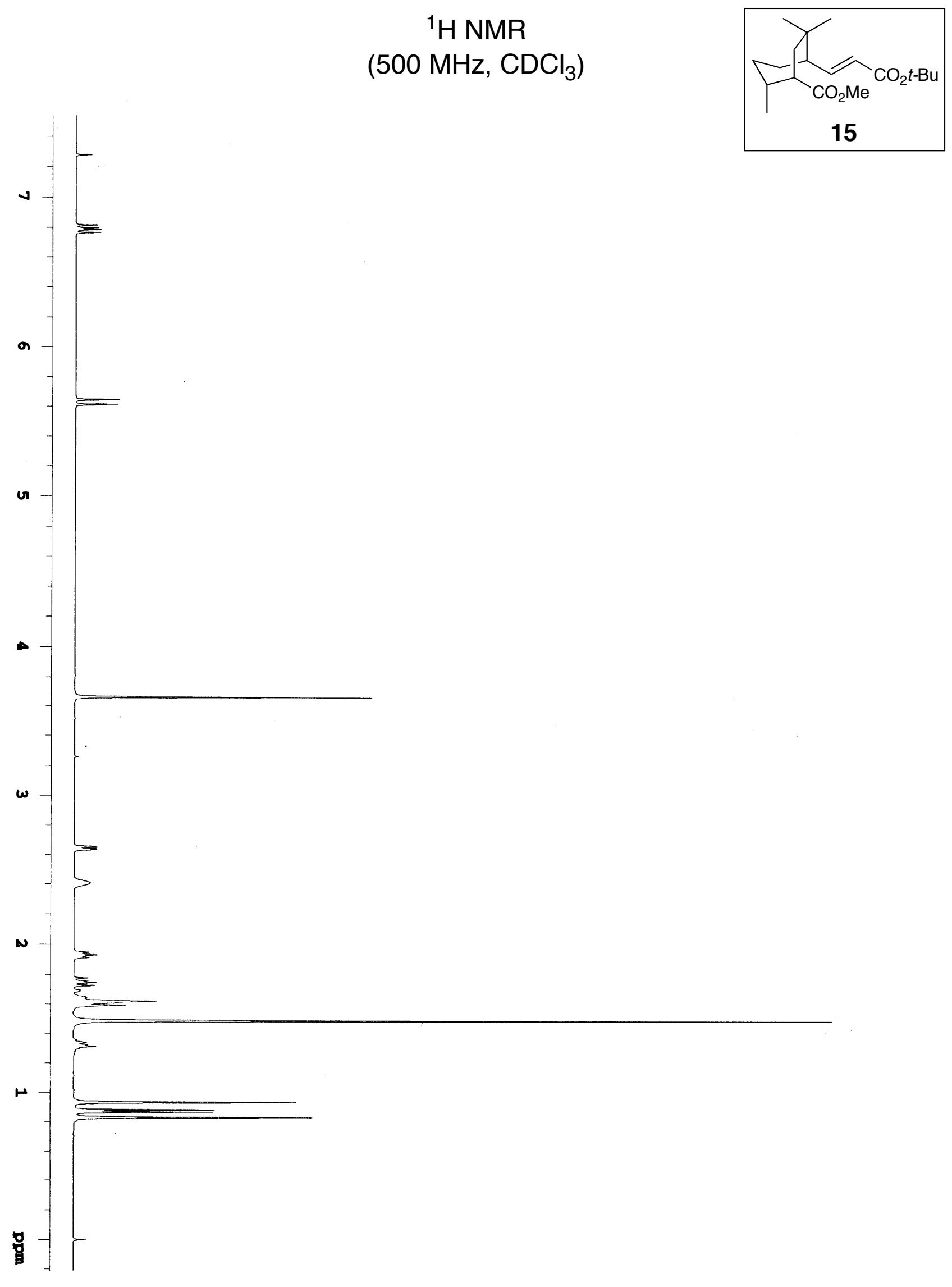


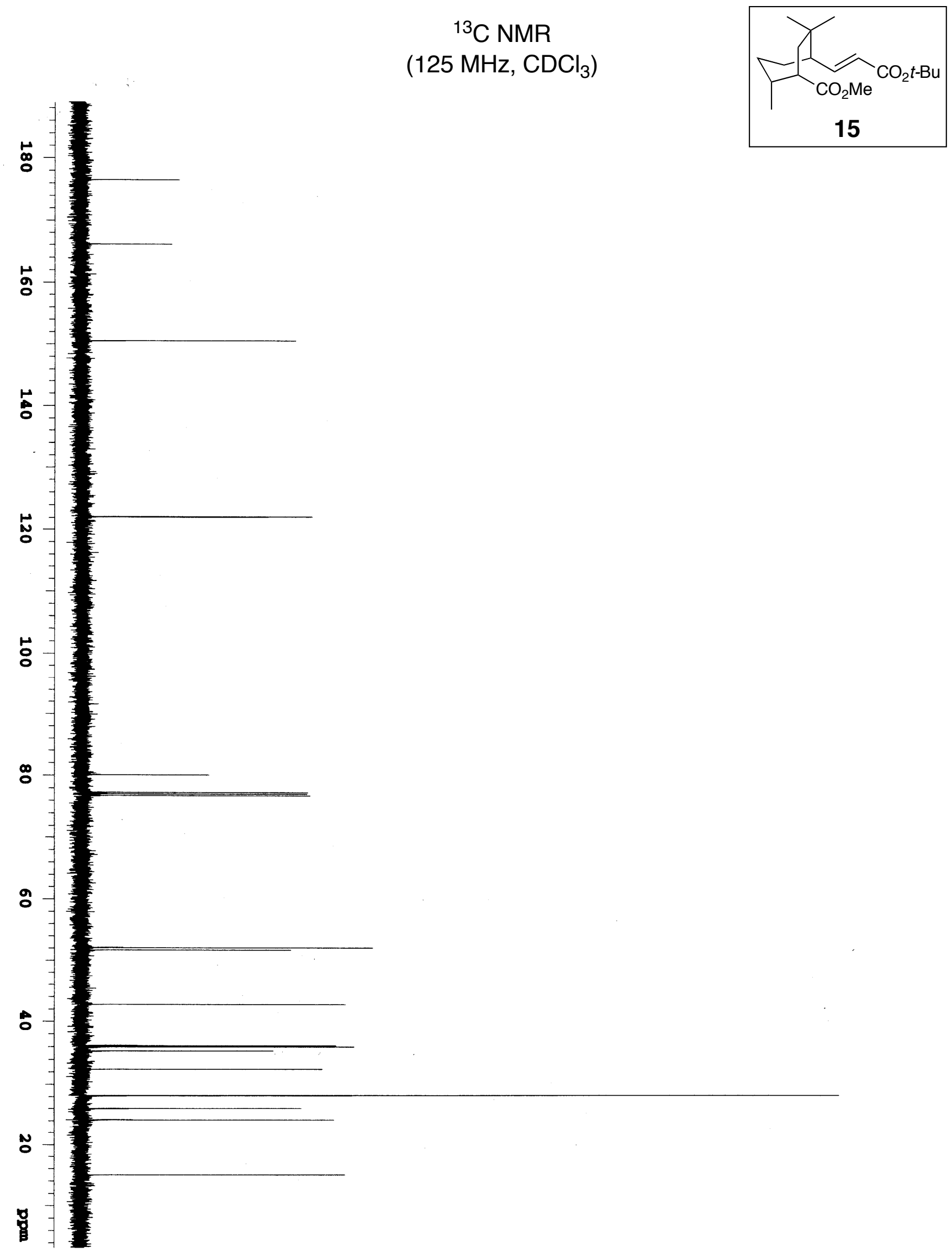




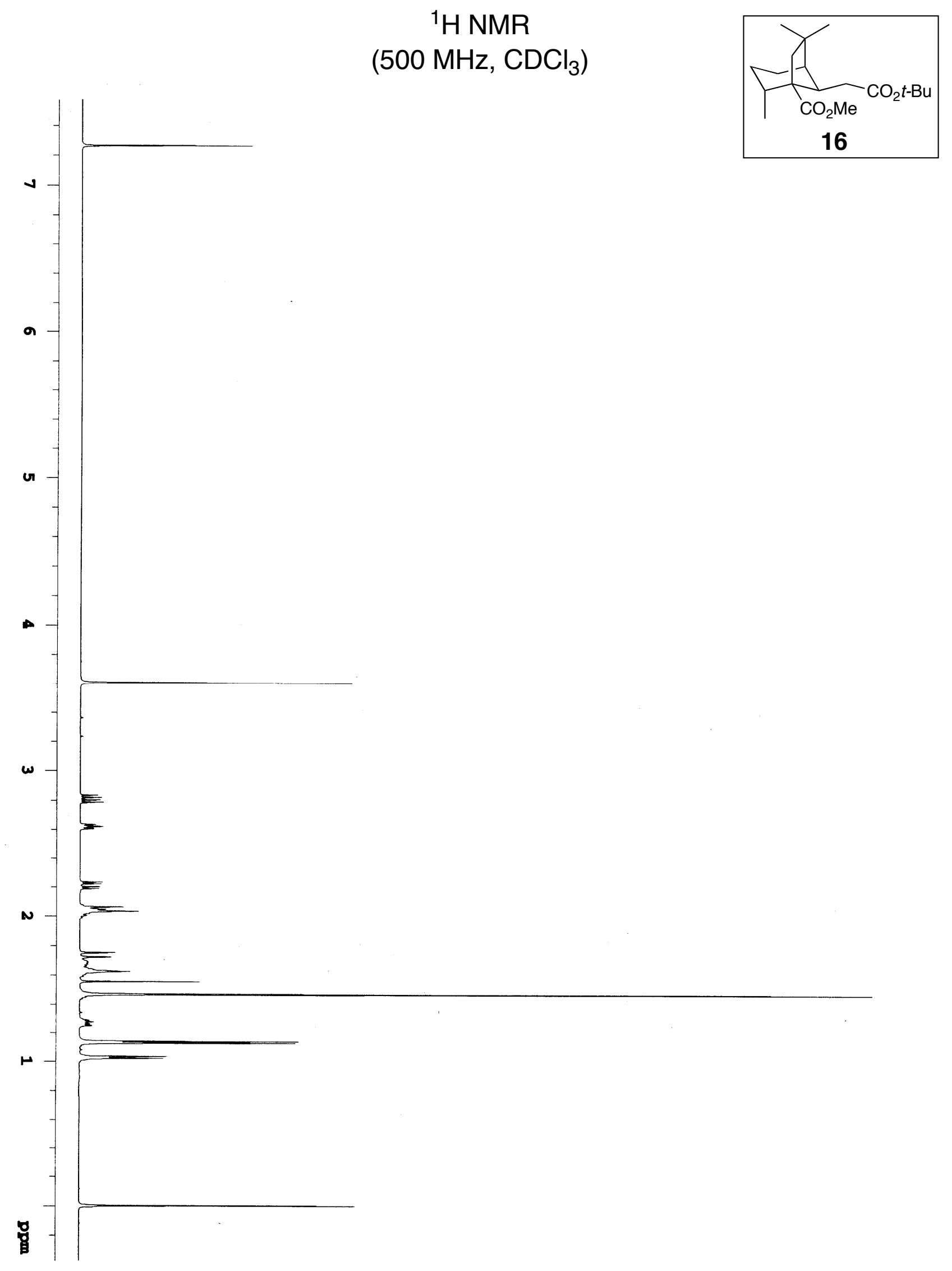


${ }^{13} \mathrm{C}$ NMR

(125 MHz, $\mathrm{CDCl}_{3}$ )

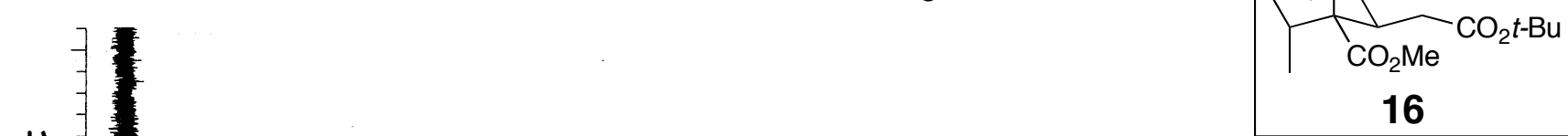

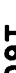

:

농

당-

\&

占

옹

\&

-

才产

음

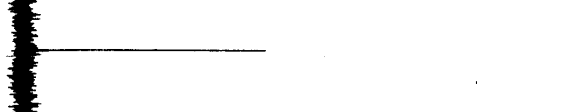

:

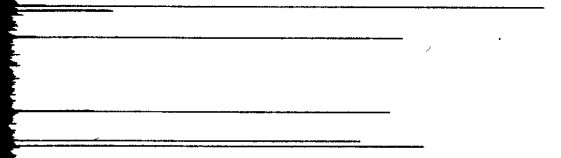

: 


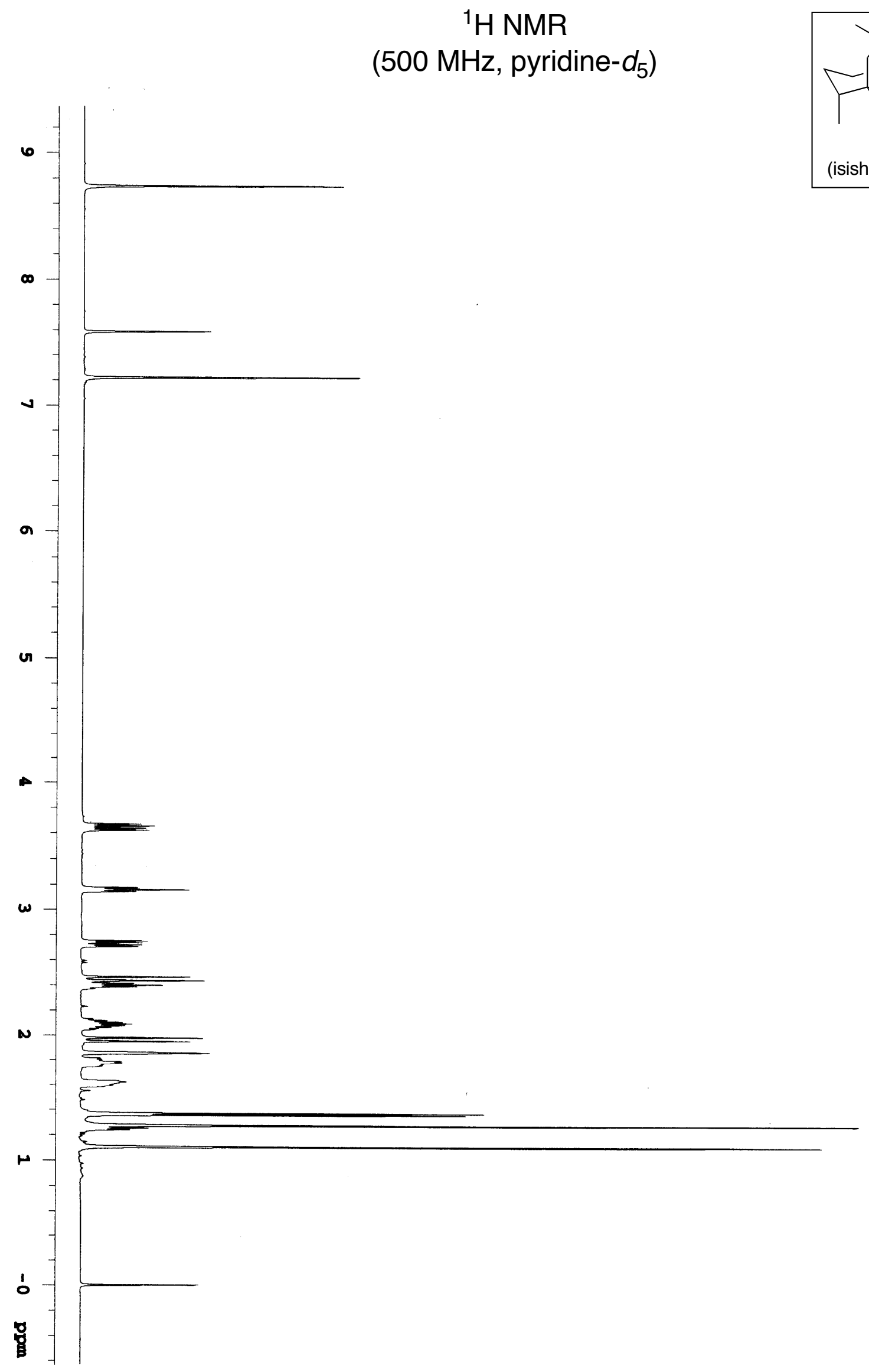

S21 


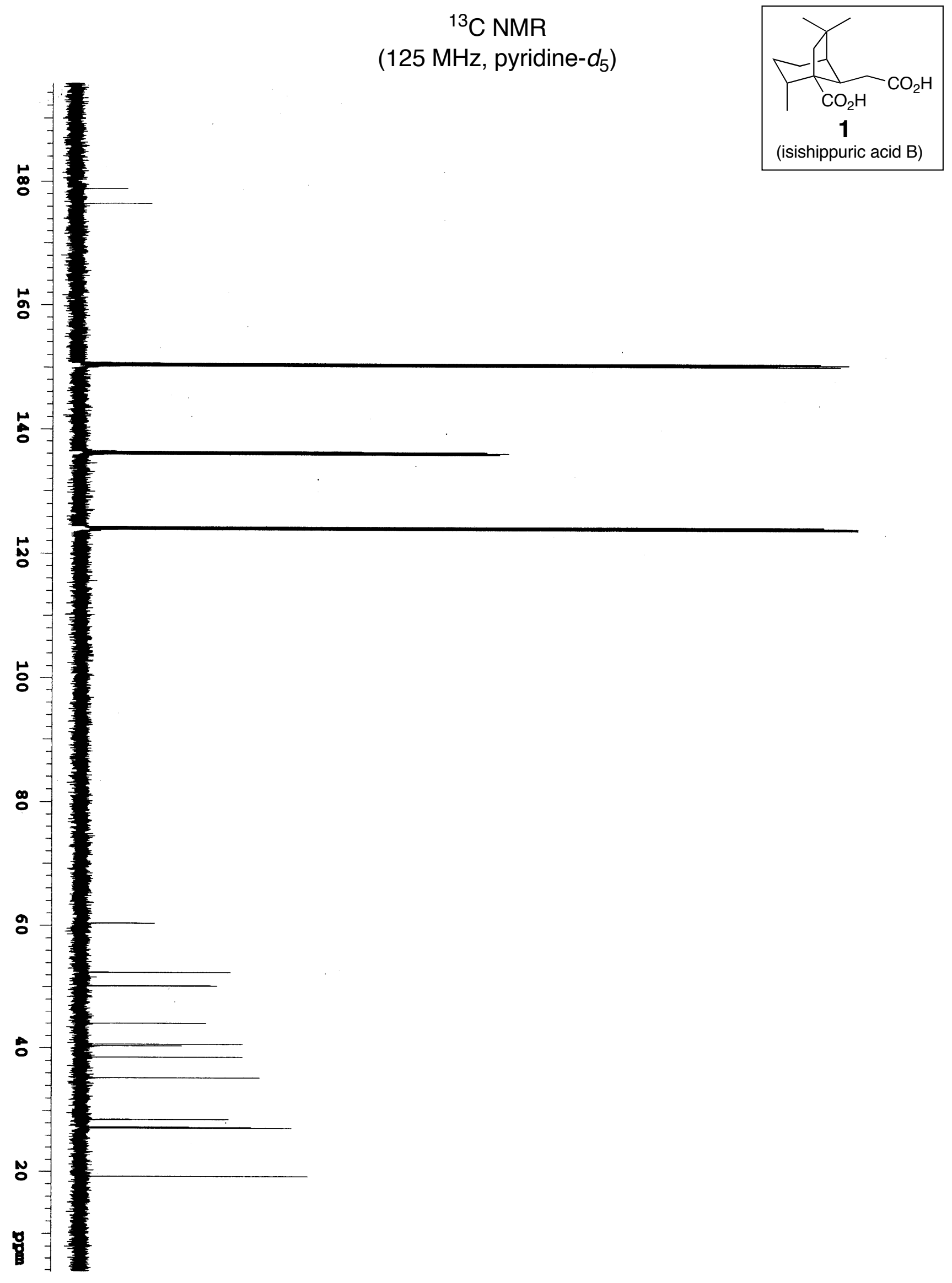

